\title{
Orientation of gravels and soft-sediment clasts in subaqueous debrites - implications for palaeo- direction reconstruction: case study from Puck Bay, northern Poland
}

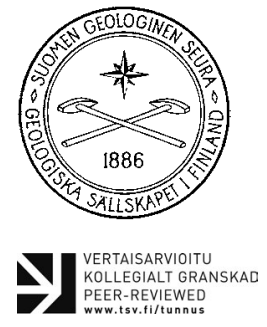
PEER-REVIEWED
www.tsv.fi/tunnus

\author{
Piotr P. WoźniaK ${ }^{1^{*}}$, MaŁgorzata Pisarska-JamrożY \\ AND ŁUKASZ ELWIRSKI ${ }^{\mathrm{I}}$ \\ ${ }^{1}$ University of Gdanisk, Department of Geomorphology and Quaternary Geology, \\ J. Bażyńskiego 4, 80-309 Gdańsk, Poland \\ ${ }^{2}$ Adam Mickiewicz University, Institute of Geology, B. Krygowskiego 12, \\ 61-680 Poznań, Poland
}

\begin{abstract}
Subaqueous debrites on a fan were recognized at Rzucewo (N Poland). Analysis of debrite fabric enabled debris-flow palaeodirections to be traced on the fan. The long axis azimuth and dip direction of lithic clasts (gravels) as well as soft-sediment clasts (SSC) were measured in the debrites. The results obtained indicate a palaeotransport direction to NNW, similar to the palaeocurrents interpreted from the asymmetrical ripples. However, detailed measurements of both gravels and SSC orientation show variability of palaeoflow directions between NW and NE sectors. In the proximal part of the fan, gravels indicate variable dip directions and dip angles, and a mostly scattered distribution of a-axis orientation. In the medial and distal parts of the fan, clasts are better ordered and usually their a-axes are oriented upslope or transverse to the palaeoslope inclination direction. Probably during the decelerating and halting of debris flows, the compression processes induced clast rotation and a change of inclination. In the distal part of the fan, debrites reveal a distinct variability of palaeoflow directions caused by flattened topography in which debris-flow lobes split and spread freely in different directions. Finally, we conclude that the individual sets of clast fabric usually indicate only local debris-flow directions.
\end{abstract}

Keywords: debris flow, palaeodirections, clast fabric, soft-sediment clasts, subaqueous fan, Pleistocene

*Corresponding author (email: geopw@ug.edu.pl)

Editorial handling: Pertti Sarala (pertti.sarala@gtk.fi) 


\section{Introduction}

Reconstruction of debris-flow palaeodirections may rely on clast fabric contained in debrites. Unfortunately, clast arrangement depends on local stress fields (Bertran et al., 1997; Major, 1998) which can cause a different clast orientation than the main debris-flow palaeodirection. Research on debrite fabric is based mostly on theoretical analyses (Takahashi, 1991; Iverson, 1997) and experiments (e.g., Van Steijn \& Coutard, 1989; Major, 1997, 1998; Iverson et al., 2010). It is usually concluded that rheological parameters for experimentally and naturally occurring debris flows are generally themselves coincident (Contreras \& Davies, 2000; Kaitna et al., 2007). However, discrepancies of matrix and framework grain-size distribution between experimentally and naturally occurring debris flows are well documented (e.g., Sosio et al., 2007). Differing lithologies in a debris-flow matrix (spatial and temporary) can cause different transport conditions and finally, different clast distributions and inclinations in debrites. As a consequence, it is still disputed whether conclusions based on experimental debris flows can be implemented to the interpretation of fabric in naturally occurring debris flows. In addition, research on debrite fabrics is usually based on subaerial slope deposits (e.g. Lawson, 1979; Mills, 1984; Major \& Voight, 1986; Eyles \& Kocsis, 1988; Nieuwenhuijzen \& Van Steijn, 1990; Bertran et al., 1997; D’Agostino et al., 2010), and very rarely on subaqueous deposits (Gravenor, 1986), as presented here. The trigger mechanisms for subaqueous gravity flows as well as transport mechanisms are widely discussed (e.g., Costa \& Williams, 1984; Haughton et al., 2009; Talling et al., 2012, 2013), but palaeoflow reconstructions are based mostly on the spatial distribution of lithofacies and measurements of ripples from turbidite sequences (e.g., Tripsanas \& Piper, 2008; Jackson \& Johnson, 2009). Furthermore, soft-sediment clasts (SSC) in debrites have not been described as a possible tool for the reconstruction of debris-flow palaeodirections before.
According to Jackson \& Johnson (2009), only the results of a complex analysis of palaeodirection measurements from all available sediments in different parts of a debris flow (from proximal to distal) can be indicative for interpretation of mean debris-flow palaeotransport directions. This is a challenge, because often only some parts of debrites are exposed. Furthermore, experimental debris flows of large volume $\left(10 \mathrm{~m}^{3}\right)$ show that a strongly aligned fabric can develop over short distances (Major, 1997, 1998).

The main objectives of the present contribution are (1) to identify debris-flow palaeodirections on a subaqueous fan and to find an answer to the question of how precise local debrite fabrics show the main debris-flow direction; (2) to check, whether the palaeodirections derived, e.g., from palaeocurrents interpreted from cross-laminated sediments, are coincident with that based on debrite fabrics (within the same fan succession); (3) to determine the most probable processes responsible for debrite fabric diversity; and (4) to evaluate the usefulness of SSC for palaeodirection reconstruction in debrites.

\section{Study site}

The study site is located in a N-S oriented cliff of Puck Bay (a part of the Gdańsk Bay; Fig. 1a, b) in the southern part of the Baltic Sea. Saalian and Elsterian sediments are present in the lowermost part of the Quaternary succession, and are succeeded by Eemian sands and gravels which followed the glaciolacustrine succession (Skompski, 2001) analysed in this study. This succession was deposited during the Middle Weichselian which is indicated by the TL and radiocarbon dating results (Olszak, 1999). The top part of the glaciolacustrine sediments is glaciotectonically deformed (Fig. 1c). Deformations are attributed to the Late Weichselian ice sheet (Woźniak et al., 2009; Woźniak \& Czubla, 2015) that deposited till covering the glaciolacustrine succession (Fig. 1c). 

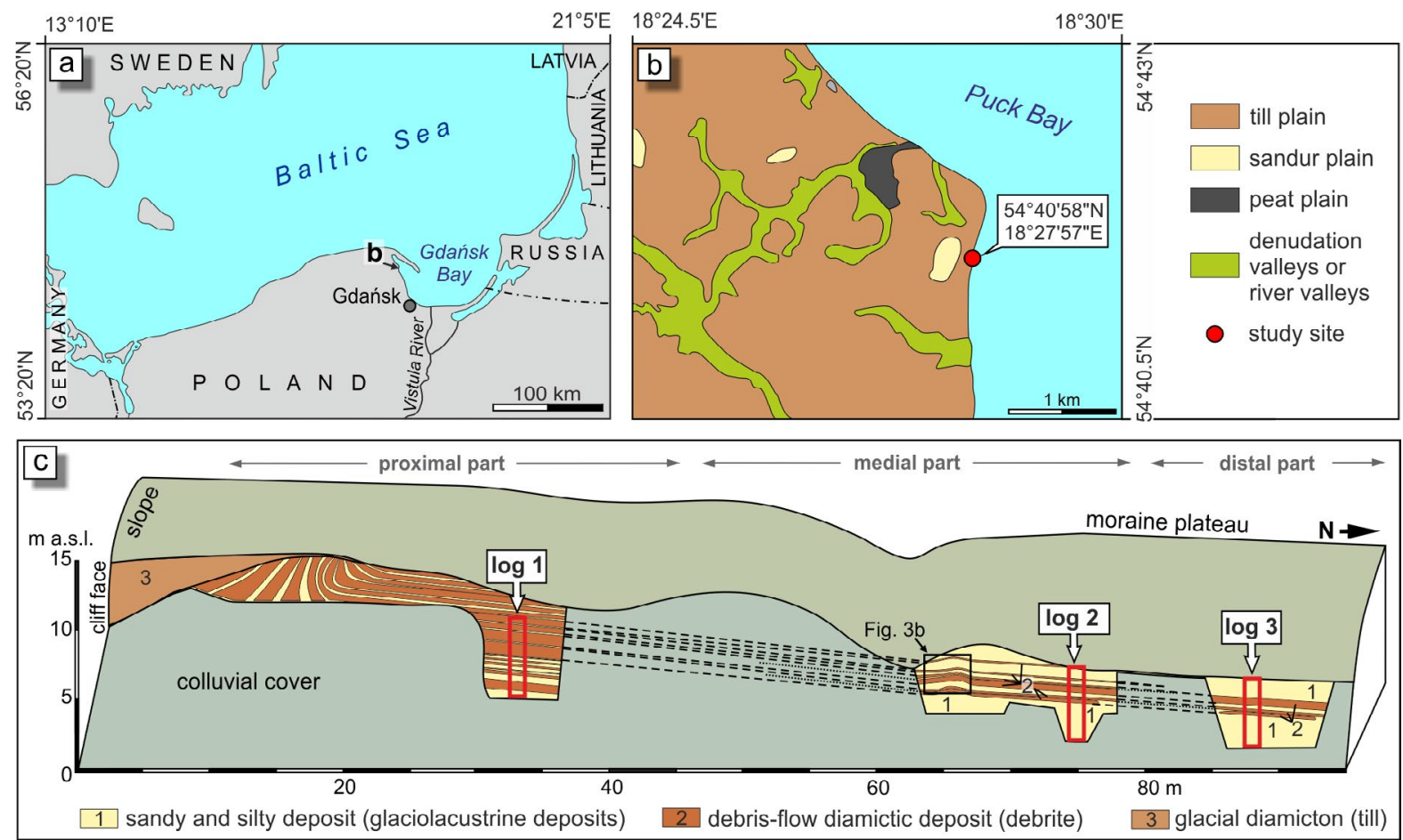

Figure 1. Location of the study site. (a) Location on the schematic map of Baltic countries. (b) Generalized geomorphological map of the study area (modified from Skompski, 2001). (c) Overview of the glaciolacustrine fan exposed in the cliff at Rzucewo.

The cliff study section is from 7 to $15 \mathrm{~m}$ in height and $80 \mathrm{~m}$ in length, and is composed of massive diamictic sediments (debrites) and laminated glaciolacustrine silts and sands (Figs. $1 \mathrm{c}$ and $2 \mathrm{a}, \mathrm{b})$. The lateral changes of sediments suggest their deposition on a subaqueous fan. The horizontally laminated silty lithofacies (TMh, Th, TSh; Fig. 2c, d) were deposited from suspension in stagnant water, wavy laminated (lithofacies $\mathrm{Tw}, \mathrm{TSw}$; Fig. 2c, d) in a waning current of a lower part of a lower flow regime, and ripple cross laminated lithofacies (TSr, STr, Sr; Fig. 2d) in the current action of a lower part of a lower flow regime (Woźniak \& Pisarska-Jamroży, 2016). Diamictic deposits, which are the main subject of the present study, were transported en masse down the palaeoslope and were deposited as debrites (Woźniak \& Pisarska-Jamroży, 2018; Fig. 2e, f).
Sedimentation took place during a recession of Middle Weichselian ice sheet, probably between ice blocks, which is deduced from (1) the lack of typical terminoglacial lacustrine sequences (cf. Brodzikowski \& Van Loon, 1991; Bennett et al., 2002; Lajeunesse \& Allard, 2002; Gruszka, 2007; Tripsanas \& Piper, 2008; Hodkin et al., 2016), (2) the lack of ice-rafted debris (Woźniak \& Pisarska-Jamroży, 2018) and (3) the proximal part of the fan occurring opposite to the presumed ice-sheet margin position in this area (north). Debrites were deposited by subaquatic debris flows of material derived from the remobilisation of unstable sediments deposited on the slope of small glaciolacustrine basin and from dead ice blocks south of this lake (Woźniak \& Pisarska-Jamroży, 2018). 

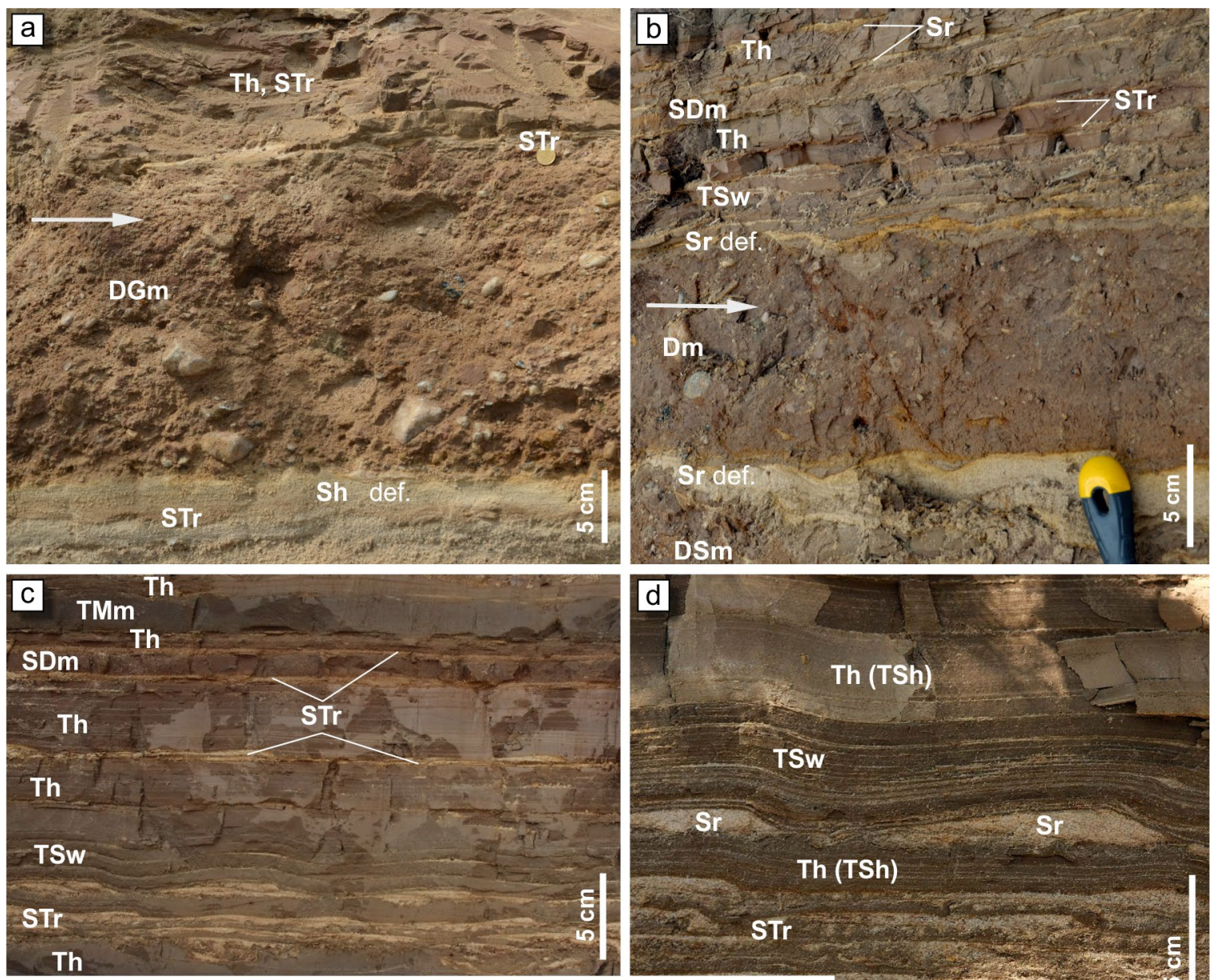

TSW

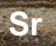

Sr

Th (TSh)

STr
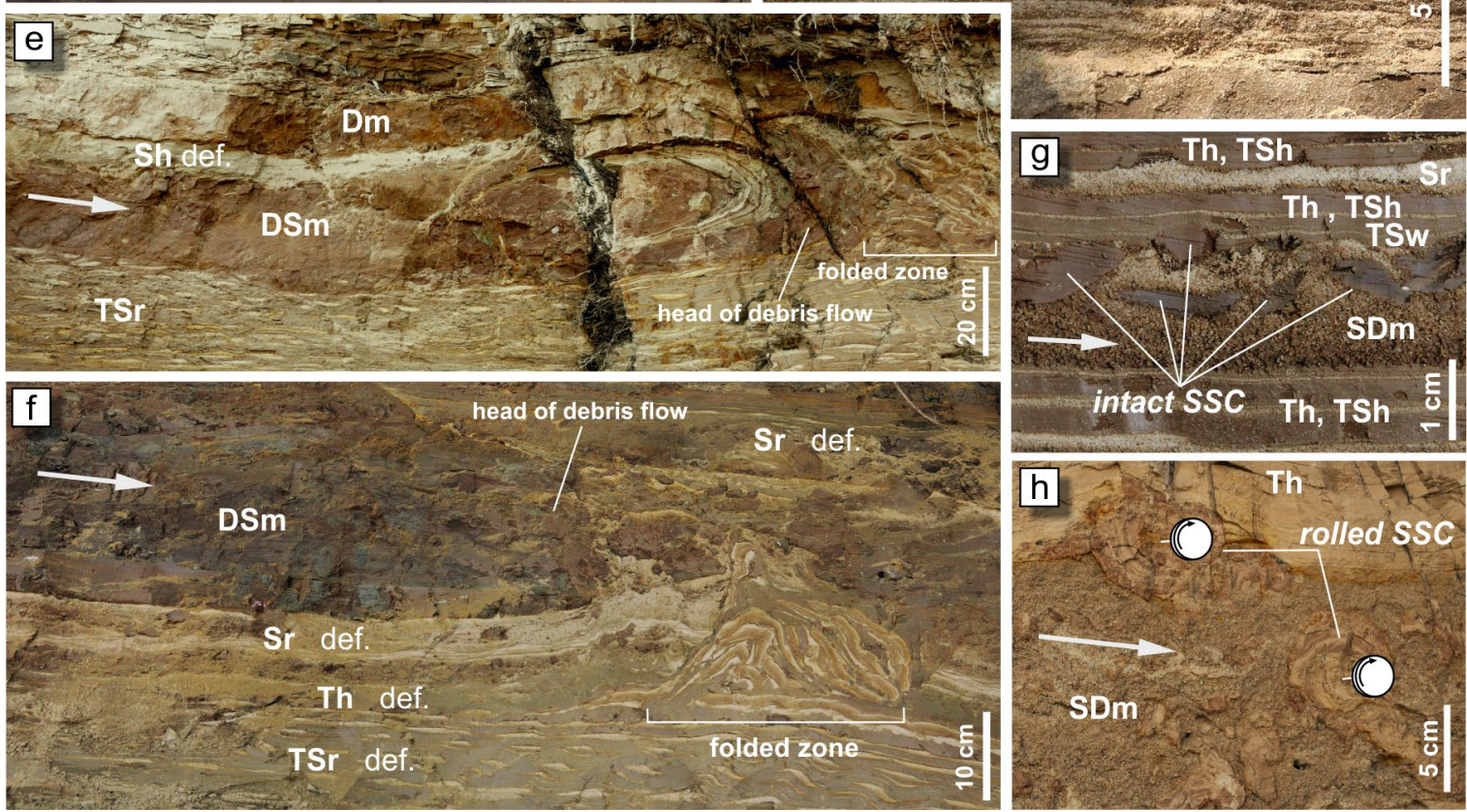


\section{Methods}

In the present study we use the term 'debrite fabric', which applies to clast dip direction and dip angle (inclination) in debrites (sediments deposited from debris-flows). The general term 'clasts' includes gravels as well as SSC. SSC contain intact clasts and contorted clasts. Intact SSC are sharp edged, subrounded or rounded and not or only slightly affected by attrition (Fig. 2g). Contorted SSC have all kinds of shapes, but they are usually irregular and internal laminae are plastically bent (Fig. 2h).

Debrite fabric was measured in ten sites (from gravels in nine sites and from SSC in one site). They were analysed on the basis of at least 30 prolate gravels in each set. The length ratio of $\mathrm{a} / \mathrm{b}$ axes of each gravel reached at least $3 / 2$, and the a-axis length - from 2 to $10 \mathrm{~cm}$. SSC were measured in an oriented block of debrite, which was cut slice by slice. Glaciotectonically deformed debrites in the upper proximal part of fan (Fig. 1c) were excluded from fabric analysis as well as debrites in the lowermost part of the succession, because they cannot be traced elsewhere in the fan.

Figure 2. Sediments of the Rzucewo sedimentary succession; for lithofacies code see explanation in Fig. 3; debris-flow palaeodirection is indicated by an arrow. (a) Massive gravelly diamicton (lithofacies DGm) with gravels in the proximal part of the fan. (b) Diamictic deposits derived from debris flows (lithofacies Dm, DSm and SDm) intercalated with silty and sandy laminated sediments in the distal part of the fan. (c) Silty sediments that dominate the distal part of the glaciolacustrine fan (commonly intercalated by thin sandy laminae and sandy ripples). (d) Sandy ripples (lithofacies Sr) measured for palaeocurrents reconstruction. (e) Massive sandy diamicton (DSm lithofacies) with preserved local head of a debris flow (debrite D1a in the medial part of the fan - see Fig. 3a). Note the increased thickness of the debrite close to the head and the folded zone in front of it. (f) Head of the debrite D1a in the distal part of the fan (see Fig. 3a). Note the system of folds and brittle deformation structures in the front of the debris-lobe head. (g) Intact soft-sediment clasts derived from glaciolacustrine silty lithofacies in the medial part of the fan. (h) Contorted, rolled soft-sediment clasts derived from laminated silty lithofacies, surrounded by diamictic sand (lithofacies SDm) in the medial part of the fan. Prolate-shaped soft-sediment clasts were extracted and their a-axis orientation was measured.
Additionally, palaeocurrent direction measurements based on dip direction and the dip angle of cross lamination in asymmetric ripples in sand and silty sand (in five sets) were made. Eigenvalues and eigenvectors were calculated according to Mark's (1973) method. Mean dip direction of clasts in debrites, and mean palaeocurrents in sand/silty sand were calculated as the mean of $\mathrm{V}_{1}$ vector azimuth. The mean palaeoflow direction of debris flows on the fan was based on inferred local directions of debris flows.

\section{Results and interpretation}

\subsection{Palaeoslope inclination direction}

\subsubsection{Description}

In the proximal part of the fan $(\log 1)$, diamictic and silty-sandy sediments are inclined $6^{\circ}$ in northern direction (Figs. 1c and 3a). Diamictic sediments dominate in the proximal (upper) part of the fan and their thickness decreases distally. In the distal part of the fan (logs 2 and 3), sediments are less inclined $\left(3^{\circ}-4^{\circ}\right)$, and silty and sandy sediments prevail. Palaeocurrent direction from sandy ripple cross-lamination (e.g., Fig. 2d) shows a very strong dip-direction concentration in all parts of the subaqueous fan. In every one of the five sets $S_{1}$ eigenvalues are considerably above 0.9 . The azimuth of the $V_{1}$ vector varies from $335^{\circ}$ to $348^{\circ}$ (Fig. 3a).

As mentioned above (see Section 2), only the top part of the succession is glaciotectonically deformed. The lower parts of the succession are undeformed in general. Only in the medial part of the fan clear thrust system with reverse faults of a vertical slip up to $10 \mathrm{~cm}$ was documented (Figs. 1c and $3 \mathrm{~b}$ ). The reverse faults are linked to a single normal fault of $10 \mathrm{~cm}$ vertical slip, open fold in the top as well as minor reverse and normal faults of a few millimetres of vertical slip. The main reverse faults dip at angles from $40^{\circ}$ to $50^{\circ}$ within NNW and $\mathrm{N}$ sectors (Fig. $3 \mathrm{~b}$ ). The dip direction of the 

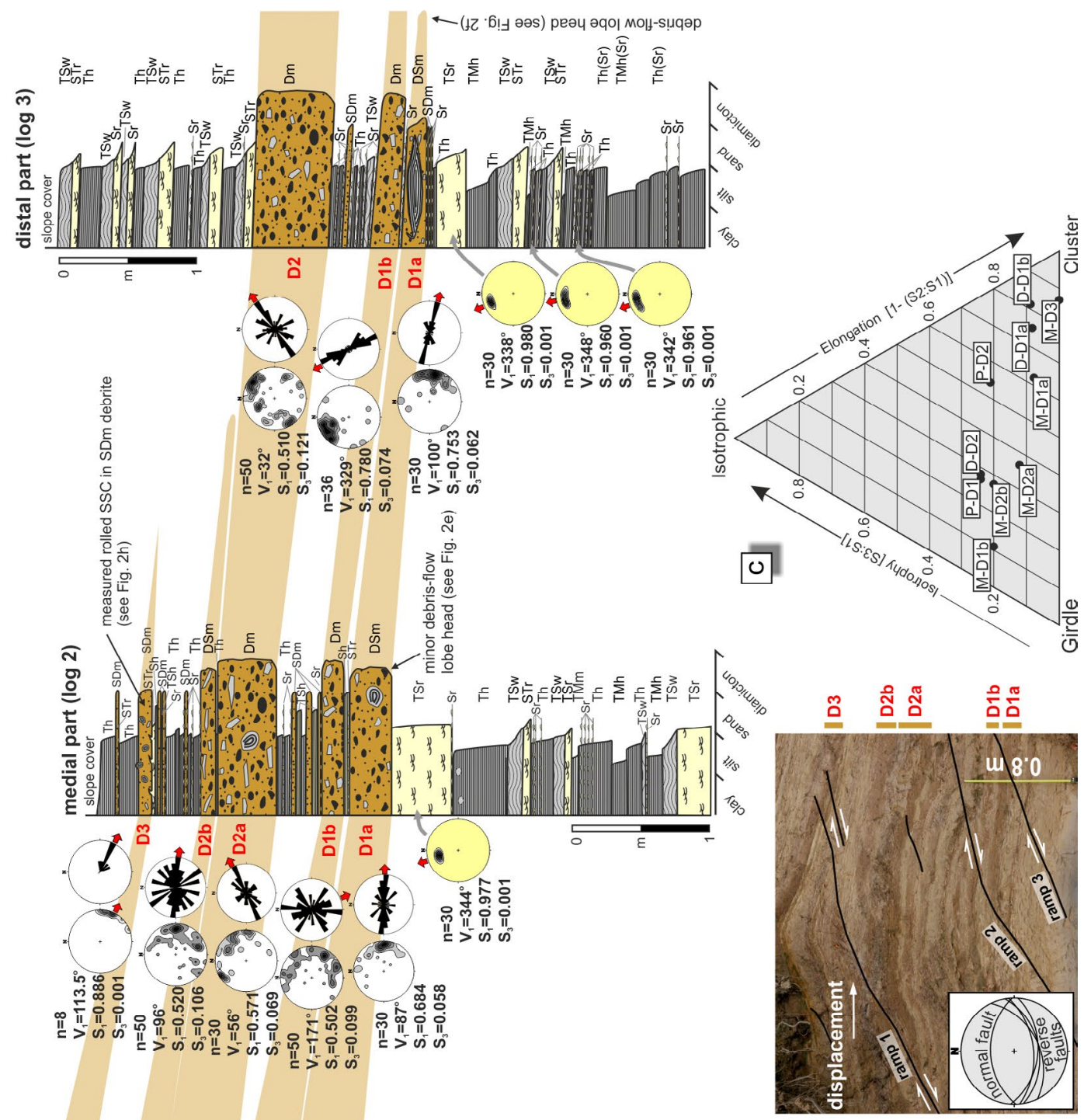

ㅇ.

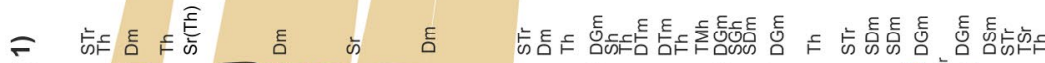

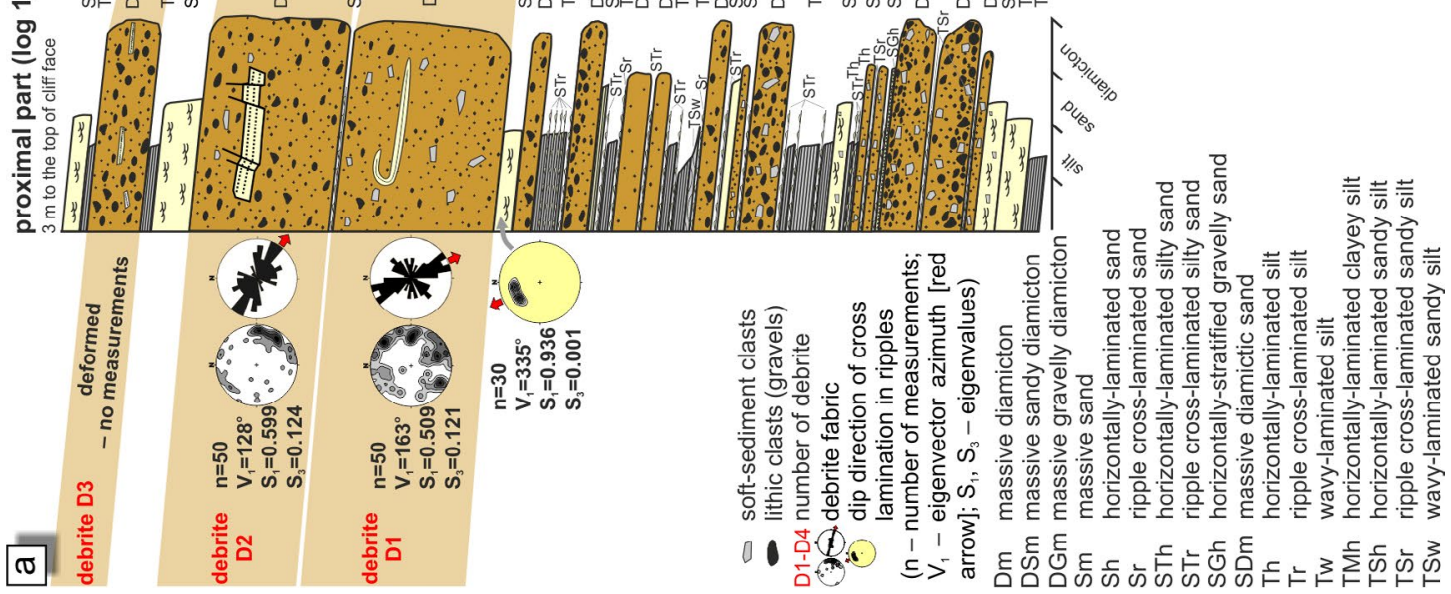


main normal fault is similar, and the mean azimuth of the main reverse and normal faults is $352^{\circ}$.

\subsubsection{Interpretation}

The results described above point to similar palaeocurrent directions, regardless of the part of the fan and regardless of sediments that were analysed. All suggest a palaeoslope dip direction to NNW (the mean azimuth is $341^{\circ}$ ), and dip angle between $6^{\circ}$ in the proximal part of the fan and $3-4^{\circ}$ in the distal part.

The thrust system described was developed by sediment displacement due to its instability on the slope (see Bathurst, 1987; Løseth, 1999). The displacement occurred after deposition of the analysed debrites towards the NNW. Additionally, the mean direction of these faults are similar but slightly different from the mean dip direction of cross lamination in asymmetric ripples, and this suggests that the direction of palaeoslope inclination after sediment accretion in general remained similar (that is NNW).

\subsection{Debrite fabric - palaeodirection implication}

\subsubsection{Description}

Debrites in the studied succession commonly contain gravels (Fig. 2a, b), usually up to $10 \mathrm{~cm}$ in diameter. Oversized gravels, up to $25 \mathrm{~cm}$, are very

Figure 3. Rzucewo sedimentary succession of the fan with interpretation; lithofacies code from Zieliński \& PisarskaJamroży (2012). (a) Overview of the debrite fabric in three sedimentary logs and presumed debrite correlation; contour diagrams are plotted on Schmidt equal area lower hemisphere nets; symmetric rose diagrams illustrate the distribution of a-axis orientation; dip direction of cross lamination in asymmetric ripples is presented in yellow filled circles. (b) Thrust system with orientation of the main faults in $\log 2$; projection of faults on the lower hemisphere. (c) Clast-fabric shape triangular eigenvalue plot; samples were collected from proximal (P), medial (M) and distal (D) parts of the subaqueous fan - see sample symbol. rare and occur only in the proximal part of the fan $(\log 1)$. Moreover, all debrites contain intact and contorted SSC. The SSC are derived from fine-grained, mostly laminated glaciolacustrine sediments (Fig. 2c, d, g) as well as from diamictic debris-flow deposits (Woźniak \& Pisarska-Jamroży, 2018). Intact SSC are most common in the proximal part of the fan, whereas both intact and contorted SSC (Fig. 2g, h) occur in the medial and distal parts of the fan (cf. Pisarska-Jamroży \& Woźniak, 2018; Woźniak \& Pisarska-Jamroży, 2018).

Gravel-clast dip directions in the proximal part of the fan were measured from two thick debrites (D1 and D2; middle part of $\log 1$; Fig. 3a). In the D1 debrite, moderate concentration and a girdle fabric shape is observed (Fig. 3a, c). The most common orientation of the gravels a-axis is SSE-NNW. They are inclined, both up and downslope, and some of them are inclined at steep angles $\left(30-64^{\circ}\right)$. Debrite D2 shows better gravel ordering than debrite D1. Long axes of gravels are clustered along SE-NE direction. Most gravels in debrite D2 reveal upslope dipping (angles mostly between 10 and $30^{\circ}$ ).

Debrites D1 and D2 in the lower part of medial and distal part of the fan are split into two (debrite D1 into D1a and D1b, and debrite D2 into D2a and $\mathrm{D} 2 \mathrm{~b}$ ). This division is confirmed by debrite fabric from the medial part of the fan (Fig. 3a, log 2 ). The D1a debrite fabric shows strong clast concentration (eigenvalue $S_{1}$ is close to 0.7). Azimuth of the $\mathrm{V}_{1}$ eigenvector is $87^{\circ}$ and almost all gravels reveal dip directions towards east. It should be noted that a minor lobe head of this debrite is observed in the outcrop. In the upper-lying D1b debrite, gravel dip is variable $\left(1-58^{\circ}\right)$, concentration is moderate $\left(S_{1} \sim 0.5\right)$ and fabric has a girdle shape. The a-axis clast orientation is well ordered (mostly upslope and eastwards). The D2a debrite fabric is characterised by moderate ordering $\left(S_{1} \sim 0.6\right)$, manifested by a moderately girdle fabric shape (Fig. 3c). Gravels in the D2a debrite dip at low angles (mostly 2-25 ) and show dip directions towards east or northeast. The azimuth of the $\mathrm{V}_{1}$ eigenvector reaches $56^{\circ}$, i.e. transverse to the 
expected inclination direction of palaeoslope. Similar, or an even more easterly direction of the $\mathrm{V}_{1}$ eigenvector, is revealed by the overlying $\mathrm{D} 2 \mathrm{~b}$ debrite $\left(97^{\circ}\right)$. Its fabric shows moderate concentration $\left(S_{1}\right.$ is 0.52$)$ and is moderately girdle-shaped (Fig. 3c). Some gravels dip at higher angles $\left(30-68^{\circ}\right)$. It should be noted that lobe head of D2b debrite is expected between medial and distal part of the fan (between logs 2 and 3). However, it is not observed in the outcrop due to thick colluvium cover.

The uppermost D3 debrite in the medial part of the fan $(\log 2)$ is thin and characterised by the lack of gravels of above a few millimetres in diameter, but it contains rolled and prolate SSC of 4-10 cm length and up to $3 \mathrm{~cm}$ in diameter. The sandy texture of this debrite enabled SSC extraction and then fabric analysis. The number of analysed SSC is low $(n=8)$, but the outstanding concentration $\left(S_{1}\right.$ close to 0.9$)$ suggests that the results can be treated as indicative. The a-axes of most SSC are inclined at very low angle (mostly at $1^{\circ}$ ) towards ESE.

In the distal part of the exposed fan $(\log 3)$ only three debrites occur. Both lowermost debrites (D1a and D1b) reveal fabric of a very strong concentration of gravel a-axis orientation $\left(S_{1}\right.$ is at 0.75 and 0.78 , respectively) and low-angled gravel dips (mostly $1-15^{\circ}$ ). However, the dip direction of gravels is almost the opposite: in the $\mathrm{D} 1$ a debrite the a-axis of gravels reaches the dominant ESE direction (from upslope through transverse to downslope), while in the D1b debrite almost all gravels are inclined towards NNW (downslope). It should be noted that the head of the D1a debrite lobe is observed in the outcrop. The fabric of the upper lying D2 debrite shows yet another direction: most gravels are aligned along a SW-NE direction, and some have a transverse orientation. Three different main dip directions of gravel (NE, SW and WNW) result in a moderate $S_{1}$ value $(0.52)$ and moderately girdle fabric shape.

\subsubsection{Interpretation}

In some analysed sets, gravels are aligned parallel to the inferred NNW direction of palaeoslope inclination. In the proximal part of the fan, the mean dip direction of gravels is opposite to that mentioned above. Gravels reveal mostly upslope inclination there. We suppose that most probably a tension process is responsible for such an orientation as the gravels sank into a moving and stretching out debris-flow sediment. In addition, the short transport distance in the proximal part of the fan resulted in only moderate clast ordering, which is clearly visible in D1 debrite. In the medial, or even more clearly, in the distal part of the fan due to a longer transport distance, better gravel-ordering occurs in the debrites. However, only results from half of the eight sets confirm this assumption, revealing a clear cluster fabric shape and high $\mathrm{S}_{1}$ value (see Fig. 3a, c: debrites D1a, D2a, D3 in log 2 and debrites D1 a and D 1 b in $\log 3$ ).

Why does debrite fabric mostly indicate palaeodirections varying from discordant to one consistent with the inclination direction of the fan palaeoslope? In the medial part of the fan $(\log 2), \mathrm{D} 1 \mathrm{~b}$ and D2b debrites show clear girdle fabric shapes (Fig. 3a, c), which resulted from the splitting of debrites D1 and D2. Remobilisation of previously deposited debrites, starting to move as individual debris flows (between proximal and medial parts of the fan) may result in weaker gravel ordering. If the down and upslope inclination direction of the gravel a-axis is omitted, the NNW direction (or close to it) prevails for both D1 and D2 debrites in the proximal part, and for D1b debrite in the medial and distal parts of the fan $(\log 2$ and 3$)$. In the main, axial part of the debris flow, clasts might achieve a long-axis orientation similar to debrisflow palaeodirection (see Fig. 4a; cf. Bertran et al., 1997; Major, 1998). Clast orientation transverse to flow direction may be tied with a position close to the debrite head (cf. Nieuwenhuijzen \& Van Steijn, 1990; Bertran et al., 1997). During the decelerating and halting of a debris flow, compression-processes induced clast rotation and a change of inclination. Clasts were ordered parallel to a local debris-flow margin and were inclined upslope (Fig. 4b). It is confirmed by the presence of a debrite head in the outcrops (Figs.2e, f and 3a). Similarly, the 

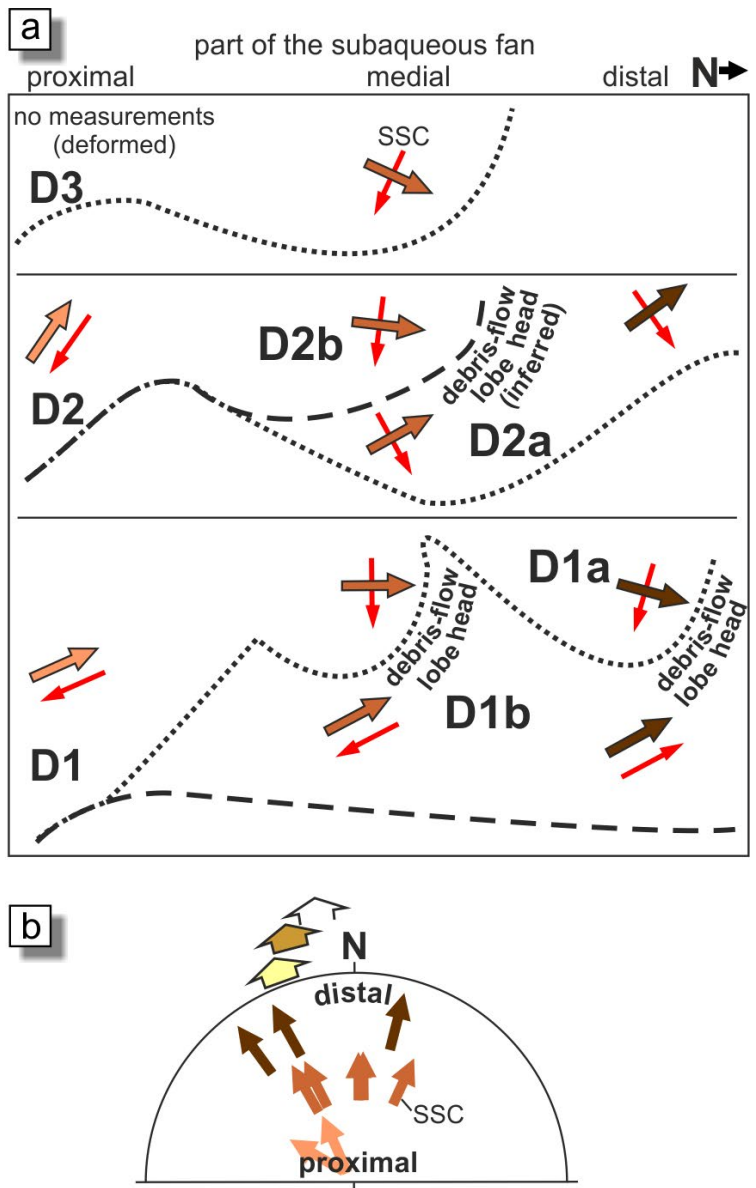

\footnotetext{
clast a-axis orientation (azimuth of the $V_{1}$ vector) inferred local debris-flow directions:

n distal

medial part of the subaqueous fan proximal

5 mean debris-flow direction based on debrite fabric

3 mean direction of palaeocurrents based on dip direction of cross lamination in asymmetric ripples

$\checkmark$ direction of palaeoslope inclination based on mean dip direction of faults
}

Figure 4. Summary of debrite fabric and inferred palaeoflow directions in the Rzucewo succession. (a) Clast a-axis orientation in a given part of debrite and inferred local debris-flow direction in selected debrites - a planar view. (b) Composite diagram of palaeoflow directions. lobe head of D2b debrite is expected between medial and distal parts of the fan (Figs. 3a and 4a). However, it is not observed in the outcrop due to thick colluvium cover. The local stress field in debris flows in contact with unmoved sediment might cause gravel rotation and at least some might get an orientation oblique to the debris-flow palaeodirection (e.g., D2a debrite in logs 2 and 3; see Fig. 3a; cf. Bertran et al., 1997; Iverson, 1997; Major, 1998).

The fabric of SSC in the D3 debrite is aligned almost horizontally, parallel to the local lower surface of debrite, whereas the inclination of debrite in the analysed part reaches $6^{\circ}$. In order to achieve their rolled structure, combined with prolate shape, they should have been rotated transverse to the palaeodirection of debris flow around their a-axis (cf. Figs. 2g, h and 5). This was possible, because SSC were transported in more fluidized debrite than other more cohesive ones (Woźniak \& PisarskaJamroży, 2018). As a consequence, local transport of D3 debrite should be determined as a direction transverse to the a-axes of rolled SSC, which means NNE (azimuth $23.5^{\circ}$ ).

Mean debris-flow palaeodirection is similar to that obtained from cross lamination in asymmetrical ripple marks and the mean dip direction of faults occurring in the succession. However, a distinct variability of palaeoflow directions is observed in debrites between NW and NE sectors (Fig. 4b), which is attributed to the radial spreading of the debris flows and their splitting into minor debrisflow lobes (Fig. 5). In the distal part, debrites reveal the most distinct variability of palaeoflow directions (they differ by $68^{\circ}$ ), because in the area of flattened topography debris flows were split into minor lobes which spread freely in different directions (Fig. 5). In contrast, debris-flow directions are most consistent in the proximal part of the fan, despite the variable dip directions of clasts and girdle fabric shapes observed there (cf. Figs. 3a and 4b). It is favoured by the steepest palaeoslope inclination in the proximal part of the fan, and as a consequence, stress field direction was parallel to debris-flow direction (Fig. 5; cf. Iverson, 1997). 


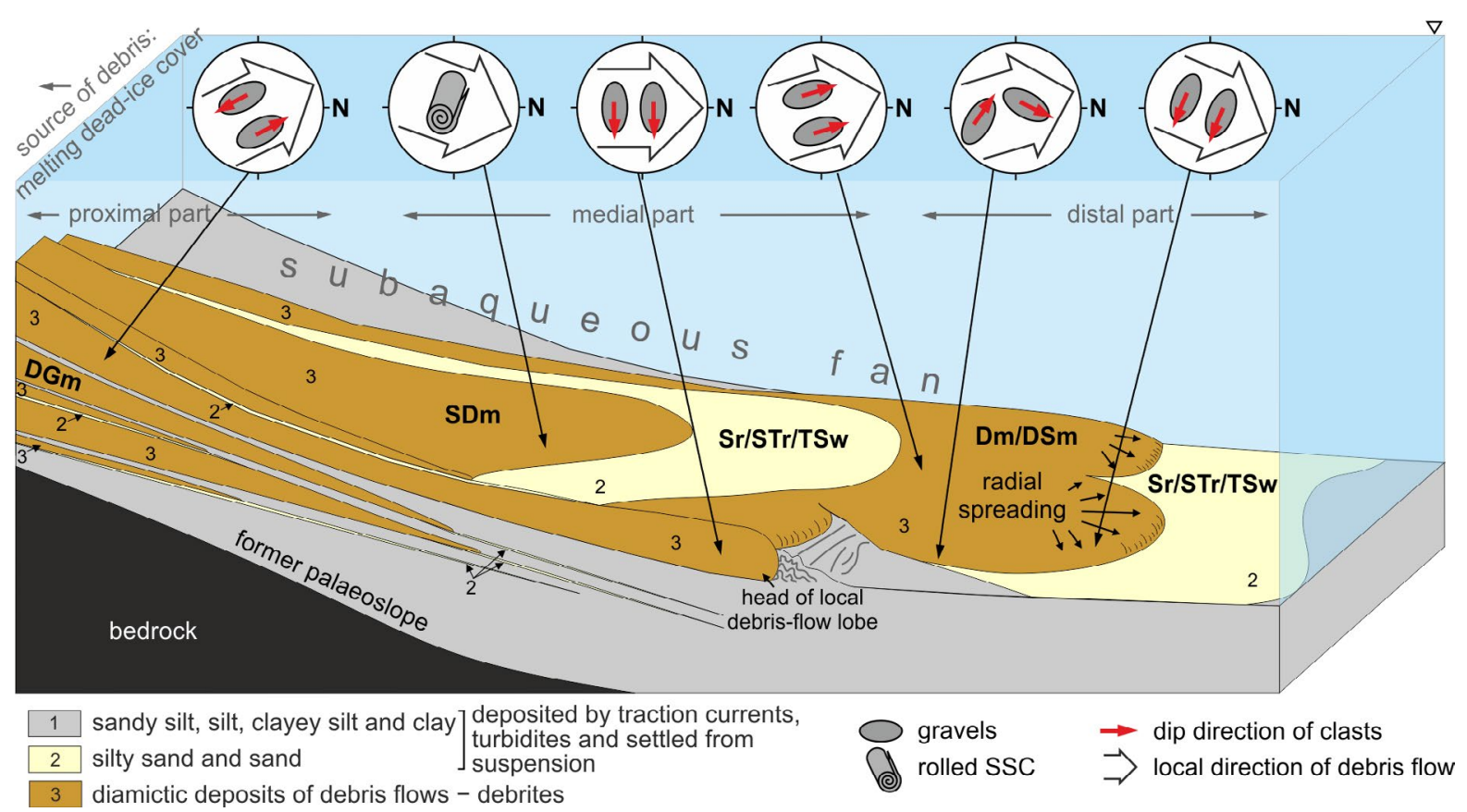

Figure 5. Model of glaciolacustrine fan deposition with clast orientation in debrites. The main orientations of clasts are shown in the circular insets. For lithofacies code see explanation in Fig. 3.

\section{Discussion}

The results from Rzucewo succession shows that in a subaqueous environment most fabric shapes of debrites are moderately developed girdles, with eigenvalue $S_{1}$ commonly between 0.5 and 0.6. However, in individual cases the strong concentrated distribution with $S_{1}>0.7$ may occur (Fig. 3a, c). These results are similar to those obtained from subaerial debrites (e.g., Lawson, 1979; Eyles \& Kocsis, 1988; Bertran et al., 1997), subaerial lahars (e.g., Mills, 1984; Major \& Voight, 1986) as well as from periglacial colluvium (e.g., Millar, 2005). Experimental debris flows show that strongly aligned fabric can develop at a distance of several meters (Major, 1997, 1998). In the Rzucewo succession, this is confirmed by results of measurements from the debrite D1b. In log 2 , clast fabric of debrite D1b is moderate $\left(S_{1}=0.5\right.$, girdle fabric shape), but 15 metres down slope $(\log 3)$ clasts are clearly better ordered $\left(S_{1}=0.78\right.$, cluster fabric shape; Fig. 3a, c). This is not visible in other debrites in Rzucewo, because the logs exposed different parts of the debrites, e.g., one $\log$ can show a lateral part of debrite, whereas the next one can show sediments of the lobe head of a given debrite (cf. Figs. 3a and 4a). In both cases local stress-field conditions play a leading role in clast ordering (Fig. 5). According to results from experimental debris flows, clast arrangement may be conditioned by surges in the flow (minor heads following one after another; Iverson, 1997; Major 1998). In Rzucewo, surges did probably not occur due the cohesive nature of most debris flows and the moderate inclination of the palaeoslope. However, the effect of different process is observed in the medial part of the fan with the splitting of the debris flows (D1 and D2 debrites are split into two; Fig. 3a). Remobilisation of previously deposited debrites, starting to move as an individual debris flow (between the proximal and medial parts of the fan) might result in weaker gravel ordering. 
In subaerial slope deposits, clast imbrication (a group of clasts with their long axes aligned parallel to the palaeodirection of debris flow) is common (Major, 1998), and is best developed in the head of the lobe where deceleration of the flow caused internal thrusting (Bertran et al., 1997). The degree of imbrication (percentage of imbricated clasts) depends on grain-size distribution: the lower the matrix content, the more possible is the imbrication arrangement (Ildefonce et al., 1992). In debrites in the Rzucewo succession, imbrication is not observed, because gravels constitute only a small percentage and are dispersed in a finegrained matrix. Moreover, some of the fine-grained debrites in Rzucewo can be attributed to deposits by mud flows (cf. Mulder \& Alexander, 2001).

Contorted, rolled SSC were transported on the subaqueous fan at Rzucewo probably in less cohesive and more fluidized debris flows than gravels (e.g., Dm and DSm debrites). The SSC became rolled due to rotation around their long axis, transverse to progressive motion (see Taylor, 1923). As a result, the long axis of SSC was transverse to the debris-flow palaeodirection (cf. Knight, 2009). Most rolled SSC at Rzucewo were buoyant and deposited in the upper part of the debrite (Fig. 2h). Even though a strong concentration of a-axis orientation means, the direction of SSC transport is slightly more eastwards than the assumed inclination of the palaeoslope (Fig. 4b). This can be caused in Rzucewo succession by (1) available debrite intersection in an outcrop - it is possible that the intersection did not cut the axial part of the debrite head with expected folded zone in front of it, as in Fig. 2e, f, or (2) the outcrop shows the lateral part of a debris flow with the a-axes of clasts oblique to the main palaeodirection of debris-flow transport (a result of local field stress between deposited and mobile deposits), but still restores the local palaeodirection of debris-flow transport.

The orientation resultant vector of SSC in debrite D3 in Rzucewo succession is similar to the vector of gravels in the underlying debrite $\mathrm{D} 2 \mathrm{~b}$ $(\log 2)$. The $\log 2$ shows the head parts of D2b and D3 debrites, so the orientation of the long axes of gravels as well as SSC comes from the radial distribution of palaeoflows in their head parts (i.e. parallel to the local palaeoflow within the head; see Fig. 5). On this basis, it can be assumed that close to the axial part of the debris flow, at a distance from the debris-flow head, the long axes of SSC in fluidized debrites and the long axes of gravels in cohesive debris flows were transverse to each other. The long axes of gravels will be parallel to the main debris-flow palaeodirection (according to local field stress in debrites), whereas the long axes of SSC (linked to the rotation process in progressive motion) will be transverse to the main debris-flow palaeodirection (Figs. 4a and 5). On the basis of this research, results for both gravels and SSC orientation can be considered as complementary, and can be used in palaeodirection reconstructions of debris flows.

Three main types of fabric can be distinguished in the debrites at Rzucewo site: (1) a-axis clast arrangement parallel to debris-flow direction - in an axial part of a debris flow; (2) clast ordering transverse to debris-flow direction - in the head of a debris-flow lobe; and (3) clasts reveal fabric oblique to palaeoflow direction - in lateral parts of a debris flow (cf. Figs. 4a and 5). Such triple division occur also in subaerial debrites (cf. Bertran et al., 1997). However, according to the results obtained from contemporary lahars (Mills, 1984; Major \& Voight, 1986), in which the flow direction is well documented, it should be concluded that some lateral parts of a given debrite may show direction inconsistent with the expected. In addition, in places where shapes of debrite fabric are well developed girdles, $\mathrm{V}_{1}$ azimuth may point at the apparent (false) direction of a flow, because the long axes of prolate-shaped clasts may be parallel or perpendicular to each other and parallel, perpendicular, transverse, or at some other angle to the dip of the palaeoslope (Gravenor, 1986). As indicated by the results from Rzucewo site, the reasons for this may be changes to the local stress field at short distances and orientation of some clasts inherited from a previous stage of a flow. 
Other factors that may affect debrite fabric are (1) clast concentration and (2) water content in a debris flow. Gravenor (1986) concluded that the bigger the clast concentration in a debris flow, the higher is the chance of clast collisions causing alignment of elongate clasts parallel to the flow direction. However, according to more recent research (e.g., Ildefonse et al., 1992; Jezek et al., 2013), the fabric diverges from the shear direction with increasing clast concentration. Unfortunately, we cannot trace clast-concentration changeability in debrite in the whole fan in detail. According to Lawson (1979), debris flows with a low water content produce debrites with a weak clast alignment, because in more cohesive debris flow intensive shearing occurs only in the lowest part of a debris flow. That is why in the distal part of the subaqueous fan at Rzucewo clasts in debrites D1a and D3 are clearly better ordered than in debrite D2a (Fig. 3a).

\section{Conclusions}

The following conclusions can be drawn from the present study:

- The fabric of debrites occurring in the Rzucewo succession indicates a palaeotransport direction to NNW - similar to palaeocurrents interpreted from asymmetrical ripples in the fan succession. Detailed measurements of clast orientation show variability of palaeoflow directions in debrites between NW and NE sectors. Two main reasons are responsible for this variability: debris-flows splitting into minor lobes and radial spreading in the debris-flow head.

- In the medial or, even more clearly, in the distal part of the fan due to a longer transport distance, better clast ordering is found in debrites. However, in the distal part of the fan, debrites reveal a distinct variability in palaeoflow direction. This variability is caused by flattened topography, on which the debris-flow lobe was split and spread freely in different directions.

- Clast a-axis arrangement parallel to the direction of palaeoflow is observed only in the axial part of debris flows. During the decelerating and halting of debris-flows, compression processes induced clast rotation and changes of inclination. Clast ordering transverse to palaeoflow direction is typical for the head of a debris-flow lobe. Clast fabric oblique to debris-flow direction may occur close to the lateral margin of a debris flow. Close to the axial part of the debris flow, the rolled and prolate soft-sediment clasts in fluidized debrites are transverse to the main debris flow direction. This is linked to their rotation in progressive motion during transport.

- Both gravels and soft-sediment clasts from subaqueous debrites can be used in reconstructions of palaeoflow directions, but the individual sets of clast fabric usually indicate only the local debris-flow direction and clast arrangement influenced by the local stress field.

\section{Acknowledgements}

The valuable comments by Nick Eyles and Mark Johnson, as well as suggestions and corrections by both editors, Jussi S. Heinonen and Pertti Sarala, have greatly helped to improve the manuscript. We are grateful to Richard Bolt for the linguistic support. 


\section{References}

Bathurst, J.C., 1987. Measuring and modelling bedload transport in channels with coarse bed materials. In: Richards, K.S. (ed.), River Channels: Environment and Process. Blackwell, Oxford, 272-294.

Bennett, M.R., Huddart, D. \& Thomas, G.S.P., 2002. Facies architecture within a regional glaciolacustrine basin: Copper River, Alaska. Quaternary Science Reviews 21, 2237-2279. https://doi.org/10.1016/S0277-3791(02)00027-6

Bertran, P., Bernard, H., Texier, J.-P. \& Van Steijn, H., 1997. Fabric characteristics of subaerial slope deposits. Sedimentology 44, 1-16. https://doi.org/10.1111/j.1365-3091.1997.tb00421.x

Brodzikowski, K. \& Van Loon, A.J., 1991. Glacigenic sediments. Developments in Sedimentology 49. Elsevier, Amsterdam, 674 pp.

Contreras, S.M. \& Davies, T.R.H., 2000. Coarse-grained debris-flows: hysteresis and time-dependant rheology. Journal of Hydraulic Engineering 126, 938-941. https://doi.org/10.1061/(ASCE)0733-9429(2000) 126:12(938)

Costa, J.E. \& Williams, G.P., 1984. Debris-flow dynamics (video). U.S.G.S. Open-File Report 84-606.

D’Agostino, V., Cesca, M. \& Marchi, L., 2010. Field and laboratory investigations of runout distances of debris flows in the Dolomites (Eastern Italian Alps). Geomorphology 115, 294-304. https://doi.org/10.1016/j.geomorph.2009.06.032

Eyles, N. \& Kocsis, S., 1988. Sedimentology and clast fabric of subaerial debris flow facies in a glacially-influenced alluvial fan. Sedimentary Geology 59, 15-28. https://doi.org/10.1016/0037-0738(88)90098-X

Gravenor, C., 1986. Magnetic and pebble fabrics in subaquatic debris-flow deposits. Journal of Geology 94, 683-698. https://doi.org/10.1086/629074

Gruszka, B., 2007. The Pleistocene glaciolacustrine sediments in the Bełchatów mine (central Poland): Endogenic and exogenic controls. Sedimentary Geology 193, 149-166. https://doi.org/10.1016/j.sedgeo.2006.01.008

Haughton, P., Davis, Ch., McCaffrey, W. \& Barker, S., 2009. Hybrid sediment gravity flow deposits-classification, origin and significance. Marine and Petroleum Geology 26, 1900-1918. https://doi.org/10.1016/j.marpetgeo.2009.02.012

Hodkin, R.G., Lee, J.R., Riding, J.B. \& Turner, A., 2016. Genesis and provenance of a new Middle Pleistocene diamicton unit at Happisburgh, NE Norfolk, UK. Proceedings of the Yorkshire Geological Society 61, 2535. https://doi.org/10.1144/pygs2015-367

Ildefonse, B., Launeau, P., Bouchez, J.L. \& Fernandez, A., 1992. Effect of mechanical interactions on the development of shaped preferred orientations: a two dimensional experimental approach. Journal of Structural Geology 14, 73-83.

https://doi.org/10.1016/0191-8141(92)90146-N

Iverson, R.M., 1997. The physics of debris flows. Reviews of Geophysics 35, 245-296.

https://doi.org/10.1029/97RG00426

Iverson, R.M., Logan, M., La Husen, R.G. \& Berti, M., 2010. The perfect debris flow? Aggregated results from 28 large scale experiments. Journal of Geophysical Research, 115, 1-29. https://doi.org/10.1029/2009JF001514.

Jackson, Ch.A.-L. \& Johnson, H.D., 2009. Sustained turbidity currents and their interaction with debrite-related topography; Labuan Island, offshore NW Borneo, Malaysia. Sedimentary Geology 219, 77-96. https://doi.org/10.1016/j.sedgeo.2009.04.008

Jezek, J., Schulmann, K. \& Paterson, S., 2013. Modified Jeffery model: Influence of particle concentration on mineral fabric in moderately concentrated suspensions. Journal of Geophysical Research: Solid Earth 118, 852-861. https://doi.org/10.1002/jgrb.50105

Kaitna, R., Rickenmann, D. \& Schatzmann, M., 2007. Experimental study on rheologic behaviour of debris flow material. Acta Geotechnica 2, 71-85. https://doi.org/10.1007/s11440-007-0026-z

Knight, J., 2009. Significance of soft-sediment clasts in glacial outwash, Puget Sound, USA. Sedimentary Geology 220, 126-133. https://doi.org/10.1016/j.sedgeo.2009.07.008

Lajeunesse, P. \& Allard, M., 2002. Sedimentology of an icecontact glaciomarine fan complex, Nastapoka Hills, eastern Hudson Bay, northern Quebec. Sedimentary Geology 152, 201-220. https://doi.org/10.1016/S0037-0738(02)00069-6

Lawson, D.E., 1979. A Comparison of the pebble orientations in ice and deposits of the Matanuska Glacier, Alaska. Journal of Geology 87, 629-645. https://doi.org/10.1086/628457

Løseth, T.M., 1999. Submarine massflow sedimentation: computer modelling and basin fill stratigraphy. Lecture Notes in Earth Sciences 82. Springer-Verlag, Berlin, 156 p. https://doi.org/10.1007/BFb0117872

Major, J.J., 1997. Depositional processes in large-scale debrisflow experiments. Journal of Geology 105, 345-366. https://doi.org/10.1086/515930

Major, J.J., 1998. Pebble orientation on large, experimental debris-flow deposits. Sedimentary Geology 117, 151-164. https://doi.org/10.1016/S0037-0738(98)00014-1

Major, J.J. \& Voight, B., 1986. Sedimentology and clast orientations of the 18 May 1980 southwest-flank lahars, Mount St. Helens, Washington. Journal of Sedimentary Research 56, 691-705. https://doi.org/10.1306/212F8A1C-2B24-11D7$8648000102 \mathrm{C} 1865 \mathrm{D}$ 
Mark, D.M., 1973. Analysis of axial orientation data, including till fabrics. Geological Society of America Bulletin 84, 1369-1374.

https://doi.org/10.1130/0016-7606(1973)84<1369:AO AODI > 2.0.CO;2

Millar, S.W.S, 2005. Fabric variability associated with periglacial mass-wasting at Eagle Summit, Alaska. Geomorphology 72, 222-237. https://doi.org/10.1016/j.geomorph.2005.05.012

Mills, H.H., 1984. Clast orientation in Mount St. Helens debris-flow deposits, North Fork Toutle River, Washington. Journal of Sedimentary Research 54, 626-634. https://doi.org/10.1306/212F848B-2B24-11D7$8648000102 \mathrm{C} 1865 \mathrm{D}$

Mulder, T. \& Alexander, J., 2001. The physical character of subaqueous sedimentary density flows and their deposits. Sedimentology 48, 269-299. https://doi.org/10.1046/j.1365-3091.2001.00360.x

Nieuwenhuijzen, M.E. \& Van Steijn, H., 1990. Alpine debris flows and their sedimentary properties. A case study from the French Alps. Permafrost and Periglacial Processes 1, 111-128. https://doi.org/10.1002/ppp.3430010204

Olszak, I., 1999. Chronostratigraphy of the western part of the cliff of Kępa Swarzewska near Jastrzębia Góra (Baltic Coast). Peribalticum 7, 41-63.

Pisarska-Jamroży, M. \& Woźniak, P.P., 2018. Debris flow and glacioisostatic-induced soft-sediment deformation structures in a Pleistocene glaciolacustrine fan: The southern Baltic Sea coast, Poland. Geomorphology, in press. https://doi.org/10.1016/j.geomorph.2018.01.015

Skompski, S., 2001. Objaśnienia do szczegółowej mapy geologicznej Polski w skali 1:50000, arkusz Puck [Detailed Geological Map of Poland in Scale 1: 50000, Explanations for Sheet Puck]. Polish Geological Institute, Warszawa, $36 \mathrm{p}$.

Sosio, R., Crosta G.B. \& Frattini P., 2007. Field observations, rheological testing and numerical modelling of a debrisflow event. Earth Surface Processes and Landforms 32, 290-306. https://doi.org/10.1002/esp.1391

Talling, P.J., Masson, D.G., Sumner, E.J. \& Malgesini, G., 2012. Subaqueous sediment density flows: Depositional processes and deposit types. Sedimentology 59, 19372003.

https://doi.org/10.1111/j.1365-3091.2012.01353.x
Talling, P.J., Paull, Ch.K. \& Piper, D.J.W., 2013. How are subaqueous sediment density flows triggered, what is their internal structure and how does it evolve? Direct observations from monitoring of active flows. EarthScience Reviews 125, 244-87. https://doi.org/10.1016/j.earscirev.2013.07.005

Takahashi, T., 1991. Debris Flow. Balkema, Rotterdam, 165 pp. Taylor, G.I., 1923. The motion of ellipsoidal particles in a viscous fluid. Proceedings of the Royal Society of London 103A, 58-61.

Tripsanas, E.K. \& Piper, D.J.W., 2008. Glaciogenic debrisflow deposits of Orphan Basin, offshore Eastern Canada: Sedimentological and rheological properties, origin, and relationship to meltwater discharge. Journal of Sedimentary Research 78, 724-744.

https://doi.org/10.2110/jsr.2008.082

Van Steijn, H. \& Coutard, J.-P., 1989. Laboratory experiments with small debris flows: physical properties related to sedimentary characteristics. Earth Surface Processes and Landforms 14, 587-596. https://doi.org/10.1002/esp.3290140614

Woźniak, P.P. \& Czubla, P., 2015. The Late Weichselian glacial record in northern Poland - a new look at debris transport routes by the Fennoscandian Ice Sheet. Quaternary International 386, 3-17. https://doi.org/10.1016/j.quaint.2015.01.014

Woźniak, P.P. \& Pisarska-Jamroży, M., 2016. Rzucewo - soft-sediment deformation structures in glaciolimnic sediments - different trigger mechanisms. In: Sokołowski, R. \& Moskalewicz, D. (eds.), Quaternary geology of north-central Poland: from the Baltic coast to the LGM limit. University of Gdańsk, Gdańsk-Gdynia, 53-67.

Woźniak, P.P. \& Pisarska-Jamroży, M., 2018. Debris flows with soft-sediment clasts in a Pleistocene glaciolacustrine fan (Gdańsk Bay, Poland). Catena 165, 178-191. https://doi.org/10.1016/j.catena.2018.01.022

Woźniak, P.P., Czubla, P., Wysiecka, G. \& Drapella, M., 2009. Petrographic composition and directional properties of tills on the NW surroundings of Gdańsk Bay, Northern Poland. Geologija 51, 59-67. https://doi.org/10.2478/v10056-009-0007-z

Zieliński, T., Pisarska-Jamroży, M., 2012. Jakie cechy litologiczne warto kodować, a jakie nie? [Which features of deposits should be included in a code and which not?]. Przegląd Geologiczny 60, 387-397. (in Polish) 